JPH: Jurnal Pembaharuan Hukum

Volume 8, Number 1, April 2021

\title{
LEGAL RESPONSIBILITY OF NOTARY DEEDS FOR ELECTRONIC ARCHIVES
}

\author{
Ani Muhammad Syuaib \\ Master of Notarial Law, Sultan Agung Islamic University \\ anisyuaib94@gmail.com \\ Imam Abdi Utama \\ Master of Notarial Law, Sultan Agung Islamic University \\ imamutama20@gmail.com \\ Teresa Irene Sumartono \\ Master of Notarial Law, Sultan Agung Islamic University \\ teresairene18@gmail.com \\ Haryono \\ Master of Notarial Law, Sultan Agung Islamic University \\ haryono2371@gmail.com \\ Mucharoroh \\ Master of Notarial Law, Sultan Agung Islamic University \\ mucharoroh76@gmail.com
}

\begin{abstract}
Deeds made by notaries as public officials are authentic deeds in accordance with the formulation of Article 1 point (7) of the Law on Notary Office, that notary deeds are authentic deeds made by or before a notary according to the form and procedure stipulated by law. The approach method in this research is juridical normative. Based on the results of data analysis, it can be concluded that the use of electronic archives at least notary deeds has not yet obtained a strong legal basis, so it does not guarantee legal certainty. Legal certainty can be achieved, if there are no provisions that conflict between one law and another. The legal substance in the use of electronic records, at least notary deeds, has not been fully accommodated in the notary office law with the obligation to read the deed in front of witnesses and not meeting these requirements will result in legal sanctions for notaries. the law on information and electronic transactions which is the legal basis for notaries also does not provide an opportunity for electronic deeds by providing limits on notary deeds that are not included in electronic documents / information, so that they cannot be used as valid evidence.
\end{abstract}

Keywords: Electronic Archives; Legal Responsibility; Notary Deeds;

\section{A. INTRODUCTION}

Notary public is a public official appointed by the government to assist the general public in terms of making existing agreements or arising in the 
Ani Muhammad Syuaib, Imam Abdi Utama, Teresa Irene Sumartono, Haryono, Mucharoroh

community. ${ }^{1}$ The existence of a notary is contained in the Civil Code, especially in Book Four on Evidence and Expiration. Then regarding the main evidence in civil law is written evidence, while the strongest written evidence is in the form of an authentic deed. Notary deed is a perfect, strongest and full tool of proof so that in addition to guaranteeing legal certainty, notarial deeds can also avoid disputes. Putting an act, agreement, stipulation in the form of a notary deed is considered better than writing it in a letter under hand, even though it is signed on a stamp duty, which was also confirmed by the signatures of the witnesses.

Currently, the existence of a notary is widely known and needed in public life, in making written evidence that is authentic so that it can be used as evidence in legal proceedings. Along with the importance of a notary, the notary has a position as a general official who has the authority to make authentic deeds and the notary is an extension of the government, which exercises some of the government's powers in the field of civil law. Therefore, the position of a notary is considered a functionary in society. ${ }^{2}$

Notary' in making deed especially related to land has very central and strategic role, for example Bond of Sale and Purchase Deed, Deed of Sale and Purchase, Deed of Right Release and others. Notary is one of the legal profession bearers (rechtsbeofenaar) by providing legal services that sustain the development process, clearly visible especially in making deed to meet the needs of the community. In fact, it is not only the judge who is obliged to make legal discovery (rechtsvinding) to solve the concrete problems he faces. $^{3}$

So far, notary services to the public are still conventional, but along with the development of information technology which inevitably forces every line of life to transmigrate from conventional systems to electronic systems, notary services are also shifting to electronic-based services, or known as cyber notary. The role of a notary is required to be able to participate in the development of technology and information, because in an electronic transaction it is very possible for the notary to intervene as a third party who is believed to be like a notary's role in conventional transactions. ${ }^{4}$

Not only do notaries have authority but also office administration obligations like a company. Notary office administration can be defined as activities of a written nature (administrative activities), such as writing a list

1 Abdul Muin, Notary's Responsibility To The Truth Of Data In The Making Of Islamic Banking Contract In Indonesia, Jurnal Pembaharuan Hukum, Volume V No. 1 April-Agustus 2018, page.47-54

2 Tri Ulfi Handayani, Agustina Suryaningtyas Anis Mashdurohatun, Urgensi Dewan Kehormatan Notaris Dalam Penegakan Kode Etik Notaris Di Kabupaten Pati, Jurnal Akta, Vol 5 No 1 Januari 2018, page.51-64

3 Hasyim Mustofa, The Role of Notary In Deed Of Sale And Purchace Agreement To Support National Development, Jurnal Pembaharuan Hukum, Volume IV No. 2 Mei-Agustus 2017, page.167-175

4 Kadek Setiadewi, I Made Hendra Wijaya, Legalitas Akta Notaris Berbasis Cyber Notary Sebagai Akta Otentik, Jurnal Komunikasi Hukum (JKH) Universitas Pendidikan Ganesha, Vol. 6 No 1, Februari 2020, page.126-134 
of deeds, a list of letters under legalized hands, a list of letters before giving credit, the bank ensures that all juridical aspects related to credit have been resolved and are believed to provide adequate protection for the bank, namely by means of credit that must be written in writing, either deed under the hand with sufficient duty stamp or notary deed which is also contained in the State Gazette Republic of Indonesia hand booked, Klapper's alphabetical list, protest list book; a wills register, and a limited liability company register book. The notary's administrative activities are inseparable from the notary's managerial expertise in carrying out filing procedures. The notary office filing is also part of the notary's administrative activities. The procedure for keeping the original or original deed and its documents is also the responsibility of the notary in order to maintain and safeguard the state archives properly and seriously.

The large number of recording activities by the notary raises its own problems in terms of storage. The storage period for these archives if they comply with the regulations regarding company documents is a minimum of 30 years. This period of time is not short and along the way there is often a risk of damage or even loss. The Regional Supervisory Council is unable to store thousands of notary protocols that are over 25 years old in the Regional Supervisory Council office because the Supervisory Council itself does not have an office to store these documents, so the notary protocols are kept in the notary office concerned. This means that the provisions of Article 63 paragraph (5) of Act No. 2 of 2014 cannot be implemented properly.

Act No. 11 of 2008 concerning Electronic Information and Transactions, hereinafter abbreviated as (ITE Law), regulates the mechanism for the use of electronic signatures, where everyone can use an electronic signature (e-signature) which is supported by an electronic certification service provider. Basically, an electronic signature and its electronic certification system are held to clarify the identity of legal subjects and protect the security and authenticity of electronic information communicated through electronic systems. ${ }^{5}$.

It cannot be denied that in everyday life and transactions, notaries have been recognized and valued as parties worthy of trust by the public. Notary is an official or legal professional who is sworn to act in accordance with the law properly, so it can be said that a notary is indispensable to ensure the legality of an act or to prevent any illegal act.

By looking at the provisions above, the writer is of the opinion that the transfer of protocols in electronic form cannot be juxtaposed with authentic evidence, considering that the deed is also part of the notary protocol. Proof of authenticity of these documents must be written on paper and made by the authorized official. Documents in electronic form are still ordinary evidence, meaning that the power of proof on electronic documents cannot be said to be the same or equivalent to the power of proof on an authentic

5 Mohamat Riza Kuswanto, Urgensi Penyimpanan Protokol Notaris dalam Bentuk Elektronik, Jurna/Repertorium, Volume IV No. 2 Juli-Desember 2017.page 
Ani Muhammad Syuaib, Imam Abdi Utama, Teresa Irene Sumartono, Haryono, Mucharoroh

deed. So that documents in electronic form cannot stand alone as valid evidence in court, unless supported by other evidence, such as testimony from witnesses or expert witnesses, even though the documents in electronic form are the results of print out.

The purpose of this research is to examine and analyze legal responsibility for notary deeds in the form of electronic documents, so that they can be known and become information to the public regarding legal certainty about products from notaries in the form of electronic documents.

\section{B. RESEARCH METHODS}

This research method is normative juridical, namely research conducted based on library materials or can be referred to as library research. ${ }^{6}$ This research uses the concept of law where, law is positive norms in the national legal system of legislation, the research is doctrinal, namely law is a manifestation of the symbolic meanings of social behavior as seen in their interactions. Non-doctrinal legal research, the approach uses qualitative research. This research is based on the legal positivist concept which states that legal norms are identical to written norms and are made and promulgated by the competent state institutions. ${ }^{7}$

\section{RESULT AND DISCUSSION}

\section{Legal Responsibility Of Notary Deeds For Electronic Archives}

The Act Number 2 of 2014 concerning Amendments to Act Number 30 of 2004, there is Article 15 regarding the authority of a notary in paragraph (1) which reads: "Notaries are authorized to make authentic deeds regarding all actions, agreements, and provisions required by the regulation. Laws and / or what the interested parties want to be stated in the authentic deed, guarantee the certainty of the date of making the deed, keep the deed, provide grosse, copy and excerpt of the deed, all of which as long as the making of the deeds is not assigned or excluded to other officials or other people specified in the law. "Based on the article above, it can be seen that the application of electronic signatures cannot be applied in deeds. However, this does not rule out the possibility that new regulations or updates will appear in the notary office law along with the times. Edmon Makarim, stated that there is no prohibition on making electronic copies, but there will be potential problems due to reading and time stamping. So that parties who transact with notaries need to agree on the time to be used in electronic transactions. ${ }^{8}$

6 Sri Mamudji, Metode Penelitian dan Penulisan Hukum, Jakarta : Badan Penerbit Universitas Indonesia, Jakarta, 2005, page.32

7 Ronny Hanitiyo Soemitro, Metodologi Penelitian Hukum, Ghalia Indonesia Jakarta, 1990, page.132.

8 R.A.Emma Nurita, CYBER NOTARY: Pemahaman Awal dalam Konsep Pemikiran, Refika Aditama, Bandung, 2012, page.8 
Based on Article 15 paragraph (1), Article 16 paragraph (1) letter b, Article 58, Article 59 and Article 63 of the Notary Position Law that notaries are responsible for keeping notaries' deeds and protocols during their tenure and will be continued by the next notary who replaces them. The work of notaries is still very much dependent on paper as a medium, so it takes a large space and expensive maintenance to secure these files. In connection with this problem, the application of information technology products can be a solution option for solving these storage problems.

Article 68 paragraph (1) of the Archives Law has stipulated that "Creators of archives and/or archival institutions can create archives in various forms and/or transfer media including electronic media and/or other media", but the notary has not implemented it. In the Amendment Notary Position Law, there is no regulation regarding the electronic storage of notary protocols. Only the elucidation of Article 15 paragraph (3) states the possibility of a notary to certify transactions conducted electronically (cyber notary). The government, through the Ministry of Law and Human Rights, began to provide legal services online with the issuance of Regulation of the Minister of Law and Human Rights Number $4,5,6$ of 2014. The absence of regulations governing electronic storage of notary protocols in Notary Position Law has created a norm vacuum. Based on Plato's view that a good country is a country based on the existence of a good (law) regulation. ${ }^{9}$

Good statutory rules are regulations that provide legal certainty so as to create a safe and peaceful atmosphere in society. Regarding the theory put forward by Van Apeldoorn regarding legal certainty which means that:

a. Legal certainty is something that can be determined from law, related to concrete things.

b. Legal certainty is legal security. One of the ways to achieve legal certainty is if there are clear and consistent rules. The laws and regulations referred to in this discussion are the implementing regulations of the Notary Position Law relating to the electronic storage of notary protocols.

Legal remedies that can be taken to realize notary protocol storage in electronic form, in the absence of laws and regulations that explicitly regulate the electronic storage of notary protocols in Notary Position Law, only in the Elucidation of Article 15 paragraph (3) which states the possibility of notaries to certify transactions conducted electronically (cyber notary) as well as the restriction provided by the ITE Law in Article 5 paragraph (4) that the electronic document does not meet the document authenticity requirements as stipulated in Article 1 number 7 of the Amendment Law and Article 1868 of the Civil Code,

9 Edmon Makarim, Notaris dan Transaksi Elektronik, Kajian Hukum Tentang Cybernotary atau Elektronik Notary, Sinar Grafika, Jakarta, 2014, page.43 
Ani Muhammad Syuaib, Imam Abdi Utama, Teresa Irene Sumartono, Haryono, Mucharoroh

makes the transfer of notary protocol storage can only function electronically as a backup, not as a binding force copy.

Therefore it is necessary to revise the relevant laws so that the electronic storage of deeds carried out by an electronic system whose operation is in accordance with the prevailing laws and regulations has the same evidentiary power as the original.

Based on the two types of deeds made by notaries, for now it is not possible to apply information technology in making electronic notary deeds. Especially in making deeds of relaas. Here, the presence of a notary in front of the parties is a must so that an official report can be made containing a description of the notary which the notary has seen and witnessed at the request of the parties.

Furthermore, when referring to the provisions of Article 5 paragraph (4) letters a and b of the ITE Law, it is known that documents made in the form of notary deeds are not included in electronic information and/or electronic documents. So that notarial deeds made electronically do not have legal force as valid evidence according to the provisions of the ITE Law. With the limitation on the meaning of electronic information/electronic documents as stipulated in Article 5 paragraph (4) letters a \& b, authentic deeds made electronically by notaries are deemed unable to be valid evidence. So, the authenticity of the deed made by the notary in this case is not fulfilled. ${ }^{10}$

The application of an electronic signature is closely related to the strength of an authentic deed. One of the conditions for an authentic deed according to Article 1868 of the Civil Code is that it must be made in the presence of an official who shows that the deed was made at someone's request. In other words, the deed must be signed in front of the official.

The same is also regulated in Article 16 paragraph (1) letter $\mathrm{m}$ which states that the notary is obliged to read the deed in front of the audience in the presence of at least two witnesses and signed at the same time by the audience, witnesses and notary and in the explanation of the article as well. it is stated that the notary must be physically present and sign the deed before the audience and witnesses.

In addition, Article 16 letter $\mathrm{c}$ of the amendment to the law on the position of notary public requires tappers to attach letters and documents and fingerprints on the Minuta Deed. Thus, the authenticity of making electronic deeds using electronic signatures can be doubted because there is no fingerprint of the intended user.

The notary's responsibility to make deeds in the form of original deeds (minuta deeds) is based on Article 16 paragraph (1) letter $b$ of the Amendment of the notary office law, that in carrying out his / her office, notaries are obliged to make deeds in the form of minuta deeds and keep them as part of the notary protocol. Technology offers a more practical, efficient, inexpensive and safe way of storing notary protocols,

10 R.A.Emma Nurita, Op.Cit, page. 45 
namely through electronic storage. The enactment of Law Number 8 of 1997 concerning Company Documents (hereinafter referred to as the Company Documents Law), is the starting point for the transfer of data in the form of letters or writing on paper (based paper) into electronic media. As stated in the consideration of the formation of this law, in the section considering the letter $f$ that technological advances have enabled records and documents made on paper to be transferred to electronic media. Based on the preamble of letter e of the Company Documents Law, media transfer is an option so that a company in storing documents does not cause economic and administrative burdens. ${ }^{11}$

However, Article 15 paragraph (3) states that in addition to authority as referred to in paragraphs (1) and (2), the Notary has other powers which are regulated in statutory regulations. Other powers are described in the elucidation of Article 15 paragraph (3), namely the authority to certify transactions conducted electronically (cybernotary), make endowment pledge deeds, and aircraft mortgages.

In accordance with the explanation of Article 15 paragraph (3), notaries can make deeds using cyber notary. However, in Article 16 paragraph (1) letter $m$ of the notary position law states that the notary must be present to read and sign the deed, besides that the deed is also doubtful whether it meets the definition of the authenticity of the deed according to Article 1868 of the Civil Code which states that the deed is authentic, namely deed which states that an authentic deed is a deed made in the form determined by law, made by and / or in front of public officials who are in power for the place where the deed was made. ${ }^{12}$

This has created a norm conflict between Article 15 paragraph (3) and Article 16 paragraph (1) letter $m$ of the notary position law. In addition, the electronic transaction certification mentioned in the explanation of Article 15 paragraph (3) is also not explained, causing the transaction to be considered a notary deed and clearly contradicting Article 16 paragraph (1) letter $m$ of the notary position law.

Cyber notary has the main obligation to carry out certification and authentication in electronic transaction traffic. Certification in this case means that the notary has the authority to act as a certification authority so that the notary can issue a digital certificate to the parties and the authentication function is related to legal aspects that must be fulfilled in the implementation of electronic transactions. ${ }^{13}$

This means that there is a need for reform of the notary position law, especially those related to the deed making process in a broad sense and cyber notary deeds in particular. The description of the

11 Desy Rositawati, I Made Arya Utama, Desak Putu Dewi kasih, Penyimpanan Protokol Notaris Secara Elektronik Dalam Kaitan Cyber Notary, Acta Comitas, Vol. 2 (2017) page.172-182

12 R.Subekti dan R.Tjitrosudibio, Kitab Undang-Undang Hukum Perdata. Pradya, Jakarta, 2009, page. 53

13 Agung Fajar Matra, Penerapan Cyber Notary di Indonesia Ditinjau dari Undang-Undang no 30 Tahun 2004 tentang Jabatan Notaris, Depok, 2012, page.58 
Ani Muhammad Syuaib, Imam Abdi Utama, Teresa Irene Sumartono, Haryono, Mucharoroh

meaning of electronic certification must also be explained whether it is the same as making an electronic deed or whether it is different. This is necessary so that in carrying out their duties, notaries can keep up with the times without violating applicable laws.

\section{Legal certainty Electronic Archives}

Advances in information and communication technology in a global context are opportunities and challenges that need serious attention. These opportunities and challenges must be answered by improving the quality and quantity of human resources and the laws that govern this, so that Indonesia can compete fairly in the service trade, especially in relation to the role of notaries. ${ }^{14}$

Notary Deed is a state archive that must be carefully preserved in order to maintain its quality and quality as perfect and strongest evidence. Storage and maintenance of these deeds are the responsibility of the notary as mandated by article 1 number 13 of Law Number 30 of 2004 concerning the Position of Notary Public as amended by Law Number 2 of 2004. This means that as long as the minimum deed is kept and maintained by the notary, all the consequences that arise are the responsibility of the notary concerned. ${ }^{15}$

Archiving practices that have been carried out in the world of notary are still using conventional media in the form of paper and stored manually. Physical storage with a long period of time, is often prone to loss and damage. For example, when the notary office moves places, often many files or minerals are scattered and lost, the lack of storage space causes many notary files scattered, fires and natural disasters. ${ }^{16}$ The loss and damage of the minuta deed are not properly accommodated in the notary position law, causing problems in the future in the interests of the client. ${ }^{17}$

In the application of electronic document, the issue of data privacy protection becomes an important issue. Data privacy includes personal data and privacy which has a broader definition and context, namely the right not to be disturbed, limited access to the control of personal information, while the protection of personal data is protection specifically regarding how the law protects, how personal data is collected, registered, stored, exploited and disseminated. ${ }^{18}$

14 Habib Adjie, Konsep Notaris Mayantara Menghadapi Tantangan Persaingan Global, Jurnal Hukum Respublica, Vol. 16, No. 2 Tahun 2017, page. 201-218

15 Naily Zahrotun Nisa, Aspek Legalitas Penyimpanan Minuta Akta Notaris Secara Elektronik, Jurnal Civic Hukum, Volume 5, Nomor 2, November 2020, page.205-219

16 Imtiyaz, Lana, Santoso, Budi, \& Prabandari, Adya P, Reaktualisasi Undang-Undang Jabatan Notaris Terkait Digitalisasi Minuta Akta Oleh Notaris, Jurnal Notarius, No. 1 Vol. 13 No 1 Tahun 2020, page.97-110

17 Triyanti, Kekuatan Pembuktian Dokumen Elektronik Sebagai Pengganti Minuta Akta Notaris. Jurnal Repertorium, Vol. 2 No. 2 Tahun 2015, page. 20-30

18 Lee.A.Bygrave, Data Privacy Law: An International Perspectives, Oxford University Press, United Kingdom, 2014, page.1 
Privacy underlies human dignity and other values such as freedom of association and freedom of speech. This has become one of the most important human rights issues of our time. Provisions regarding privacy are the individual's right not to be challenged at home and the confidentiality of personal communications. ${ }^{19}$ Indonesia has adopted the International Covenant on Civil and Political Rights or the European Convention on Human Rights.

Indonesia already has regulations regarding the protection of personal data in the digital world. Protection of personal data is regulated in the Regulation of the Minister of Communication and Information of the Republic of Indonesia (Permenkominfo RI) Number 20 of 2016 concerning Protection of Personal Data in Electronic Systems which was stipulated on November 7, 2016, and promulgated and effective since December 1, 2016. In Article 1 paragraph (1) This regulation defines personal data as certain personal data which is stored, maintained, and maintained for the truth as well as its confidentiality is protected. Article 2 of this regulation states that the protection of personal data in electronic systems includes protection against the collection, collection, processing, analysis, storage, appearance, announcement, transmission, dissemination and destruction of Personal Data.

Notary protocols that are stored electronically such as print out, scanning microfilm, hard disks or flash drives and storage media other, namely non-paper information storage devices that have a level of security that can guarantee the authenticity of the documents transferred to them, as well as electronic documents that have been regulated as evidence recognized in court in the form of material law through the Company Documents Law and the transaction law electronic. Apart from the transfer of documents in electronic form, the original manuscripts still have the power of authentic proof as long as they are made by the competent authority and the original manuscripts must be kept.

And referring to Article 1888 of the Civil Code that the power of proof of written evidence is in the original deed. In the process of proof in court, if only electronic documents can be submitted by a notary as evidence, and are not included with the original (original deed) as ordered in Articles 66 and $66 \mathrm{~A}$ of the notary office law and Regulation of the Minister of Law and Human Rights number M.03.HT.03.10. In 2007, the notary is obliged to provide information, reasons and credible evidence to the investigator or judge regarding the missing or nonexistent minuta (original deed) of the deed, so that the notary can provide other evidence such as a copy of the notary deed. to the investigator or judge, if against the minuta (original deed) a notary has issued a copy of the deed.

19 David Banisar and Simon Davis, Global Trends in Privacy Protection: An International Survey of Privacy, Data Protection, and Surveillence Laws and Development, Paper, 1999, page.1-5 
Ani Muhammad Syuaib, Imam Abdi Utama, Teresa Irene Sumartono, Haryono, Mucharoroh

A copy of the notary deed and electronic document, both of which can be used as mutually reinforcing evidence. In principle, a copy of the notary deed which is used as a photocopy, scan or print out in each trial must still be presented in the original because in Article 1889 paragraph (2) of the Civil Code, it has been determined that: "If the original deed exists, then the copies and summary "The summary can only be trusted, only copies and summaries are true to the original, which can always be ordered to show".

Until now, there is no statutory regulation that discusses the extent to which electronic documents are similar or identical in the form of scans, printouts or print outs with the originals. In general, the acknowledgment of the validity of identical scans, printouts or printouts of electronic documents with originals is if the parties are able and able to show the originals at court. As long as the original cannot be shown, the evidence cannot be used and must be accompanied by other evidence that can strengthen the evidence.

Legal remedies that can be taken to realize notary protocol storage in electronic form, in the absence of laws and regulations that explicitly regulate the electronic storage of notary protocols in the notary office law, only in the Elucidation of Article 15 paragraph (3) which states the possibility of notaries. to certify transactions conducted electronically (cyber notary) as well as the restrictions provided by the electronic transaction law in Article 5 paragraph (4) that the electronic document does not meet the document authenticity requirements as stipulated in Article 1 point 7 of the Amendment notary office law and Article 1868 of the Civil Code, making the transfer of the notary protocol storage electronically can only function as a back up, not as a binding copy. Therefore it is necessary to revise the relevant legislation so that the electronic storage of deeds carried out by an electronic system whose operation is in accordance with the prevailing laws and regulations has the same evidentiary power as the original.

An electronic document form can have authentic and original proof if it uses an electronic system safely, reliably, and responsibly. However, according to Indonesian positive law, the notary deed related to the enforcement of cybernotary is not recognized as electronic evidence. This is because there is an Article that prohibits it, namely Article 5 paragraph (4) of Law Number 11 of 2008 regarding Electronic Information and Transactions, which reads: "Provisions regarding electronic information and / or electronic documents as referred to in paragraph (1) do not apply to:

a. A letter which according to the law must be made in writing; and

b. Letters and documents which according to the law must be made in the form of notary deeds or deeds drawn up by the deed-making official. " 
Thus, if it is related to a notary deed to the enforcement of cyber notary where the notary deed is electronic (electronic deed), then the power of the notary deed does not have perfect proof like an authentic deed, this is because notary deeds are electronic does not meet the requirements of an authenticity deed, apart from that Law Number 2 of 2014 and Law Number 11 of 2008 concerning Electronic Information and Transactions also has not accommodated this.

\section{CONCLUSION}

The application of electronic archives as a minimum of a notary deed has not received a strong legal basis, so it does not guarantee legal certainty. Legal certainty can be achieved, if there are no provisions that conflict between one law and another. The opportunity for a notary to make deeds electronically cannot be applied because there is no synchronization (contrary to) the law on notary office and the law on electronic transactions. Article 16 paragraph (1) letter $m$ of the notary office law requires the notary to read the deed in front of an audience in front of at least 2 (two) witnesses. Whereas Article 5 paragraph (4) of the law on electronic transactions which provides a limitation by not including notarial deeds is not included in the category of electronic information / documents.

\section{BIBLIOGRAPHY}

\section{Book:}

Agung Fajar Matra, 2012, Penerapan Cyber Notary di Indonesia Ditinjau dari Undang-Undang no 30 Tahun 2004 tentang Jabatan Notaris, Depok;

Edmon Makarim, 2014, Notaris dan Transaksi Elektronik, Kajian Hukum Tentang Cybernotary atau Elektronik Notary, Sinar Grafika, Jakarta;

Lee.A.Bygrave, 2014, Data Privacy Law: An International Perspectives, Oxford University Press, United Kingdom;

R.A.Emma Nurita, 2012, CYBER NOTARY: Pemahaman Awal dalam Konsep Pemikiran, Refika Aditama, Bandung;

Ronny Hanitiyo Soemitro, 1990, Metodologi Penelitian Hukum, Ghalia Indonesia Jakarta;

R.Subekti dan R.Tjitrosudibio, 2009, Kitab Undang-Undang Hukum Perdata, Pradya, Jakarta;

Sri Mamudji, 2015, Metode Penelitian dan Penulisan Hukum, Jakarta : Badan Penerbit Universitas Indonesia, Jakarta; 
Ani Muhammad Syuaib, Imam Abdi Utama, Teresa Irene Sumartono, Haryono, Mucharoroh

\section{Journal:}

Abdul Muin, Notary's Responsibility To The Truth Of Data In The Making Of Islamic Banking Contract In Indonesia, Jurnal Pembaharuan Hukum, Volume V No. 1 April-Agustus 2018;

David Banisar and Simon Davis, Global Trends in Privacy Protection: An International Survey of Privacy, Data Protection, and Surveillence Laws and Development, Paper, 1999;

Desy Rositawati, I Made Arya Utama, Desak Putu Dewi kasih, Penyimpanan Protokol Notaris Secara Elektronik Dalam Kaitan Cyber Notary, Acta Comitas, Vol 2 (2017);

Habib Adjie, Konsep Notaris Mayantara Menghadapi Tantangan Persaingan Global, Jurnal Hukum Respublica, Vol. 16, No. 2 Tahun 2017;

Hasyim Mustofa, The Role of Notary In Deed Of Sale And Purchace Agreement To Support National Development, Jurnal Pembaharuan Hukum, Volume IV No. 2 Mei-Agustus 2017;

Imtiyaz, Lana., Santoso, Budi., \& Prabandari, Adya P, Reaktualisasi UndangUndang Jabatan Notaris Terkait Digitalisasi Minuta Akta Oleh Notaris, Jurnal Notarius, No. 1 Vol. 13 No 1 Tahun 2020;

Kadek Setiadewi, I Made Hendra Wijaya, Legalitas Akta Notaris Berbasis Cyber Notary Sebagai Akta Otentik, Jurnal Komunikasi Hukum (JKH) Universitas Pendidikan Ganesha, Vol. 6 No 1, Februari 2020;

Mohamat Riza Kuswanto, Urgensi Penyimpanan Protokol Notaris dalam Bentuk Elektronik, Jurnal Repertorium, Volume IV No. 2 Juli-Desember 2017;

Naily Zahrotun Nisa, Aspek Legalitas Penyimpanan Minuta Akta Notaris Secara Elektronik, Jurnal Civic Hukum, Volume 5, Nomor 2, November 2020;

Tri Ulfi Handayani, Agustina Suryaningtyas Anis Mashdurohatun, Urgensi Dewan Kehormatan Notaris Dalam Penegakan Kode Etik Notaris Di Kabupaten Pati, Jurnal Akta, Vol. 5 No. 1 Januari 2018;

Triyanti, Kekuatan Pembuktian Dokumen Elektronik Sebagai Pengganti Minuta Akta Notaris. Jurnal Repertorium, Vol. 2 No. 2 Tahun 2015; 